Vol. 3, No. 2, June 2021 e-ISSN: 2656-4882 p-ISSN: 2656-5935

\title{
Penerapan Model Unified Theory of Acceptence And Use of Technology 2 Terhadap Perilaku Pelanggan e-Commerce Shopee Indonesia Di Kota Palembang
}

\author{
Andi Nur Sheila Fatihanisya ${ }^{1}$, Susan Dian Purnamasari* ${ }^{2}$ \\ 1,2Information System Department, Universitas Bina Darma, Palembang, Indonesia \\ Email: ${ }^{1}$ andinursheila15@gmail.com, ${ }^{2}$ susandian@binadarma.ac.id
}

\begin{abstract}
The developing of marketplace makes many changes in commerce. Start from conventional way and now become online shopping. One of the biggest marketplaces in Indonesia is Shopee. Due to the massive electronic commerce activity, this study aimed to know the factor that influenced behavioral intention and use behavior of shopee's user. This study adopted UTAUT 2 model which has seven variables; performance expectancy, effort expectancy, social influence, facilitating condition, hedonic motivations, price value and habit also moderated by age, gender, and experience. The analysis of the model was conducted by using SEM-PLS method and analyzed with SmartPLS 3. The data of this study was collected by using questionnaire and designed only for Shopee user who stayed in Palembang. The result show if behavioral intention influenced by social influence with $\mathrm{T}$ value is $1.985, \mathrm{P}$ value is 0.048 and $\mathrm{F}$ square is 0.105 and also influenced by habit with $\mathrm{T}$ value is 4.755 , $P$ value is 0,000 and $F$ square is 0,512 which achieved the standard value in this study. In other side, this study shows if use behavioral influenced by facilitating condition with $2.762 \mathrm{~T}$ value , $0,006 \mathrm{P}$ value and $0,140 \mathrm{~F}$ square.

Keywords : Shopee, UTAUT 2, behavioral intention, SEM-PLS
\end{abstract}

\section{PENDAHULUAN}

Berbelanja di dalam jaringan (daring) telah menjadi fenomena baru di Indonesia. Hal ini dikarenakan perkembangan teknologi yang pesat dan membuat pergeseran perilaku berbelanja masyarakat. Pergeseran perilaku tersebut terjadi karena berbelanja daring memberikan banyak kemudahan, seperti ketersediaan berbagai macam produk dan metode pembayaran, bisa melakukan transaksi kapanpun dan dimanapun lalu dapat membandingkan harga serta kualitas produk sehingga terciptanya fleksibilitas. Berbelanja online dapat dilakukan menggunakan berbagai platform seperti media social ataupun aplikasi marketplace. Secara singkat, segala bentuk transaksi bisnis dengan menggunakan internet sebagai medium pertukaran barang atau jasa dapat disebut dengan e-commerce. E-commerce pula dapat diartikan dengan sangat luas, tidak hanya tentang proses jual beli barang dan jasa 
tetapi juga tentang bagaimana pelayanan terhadap pelanggan, hubungan kerja sama dengan UMKM atau rekan bisnis serta bagaimana proses transaksi elektronik yang aman dan cepat. Untuk transaksi pembelian melalui e-commerce sendiri pada bulan maret 2020 mencapai 98,3 juta transaksi. Angka tersebut meningkat 18,1\% dari bulan sebelumnya [10]. Tak hanya itu, total nilai transaksi e-commerce juga meningkat 9,9\% menjadi Rp. 20,7 triliun dari bulan februari 2020 dan shopee adalah e-commerce ter-favorite dalam 3 bulan terakhir (Mei, Juni, Juli 2020). Hal ini sejalan dengan peta persaingan e-commerce Indonesia bulan Juli 2020, di mana Shopee juga berada diurutan teratas dengan total rata-rata kunjungan per-bulannya sebanyak 93,4 juta disusul oleh Tokopedia, Bukalapak dan Lazada [3]. Oleh karena itu penting untuk mengetahui faktor yang mempengaruhi behavioral intention pelanggan shopee untuk digunakan sebagai pedoman meningkatkan kualitas layanan. Salah satu cara untuk mengetahui faktor yang mempengaruhi behavioral intention adalah dengan penerapan model UTAUT 2 yang didalam memiliki tujuh variabel yang dapat diuji dan disertai dengan variabel moderator.

Mengetahui faktor yang mempengaruhi behavioral intention sangat penting karena niat perilaku (behavioral intention) adalah prediksi yang sangat bagus untuk penggunaan teknologi oleh pengguna teknologi. Perilaku pelanggan juga dapat dipengaruhi langsung oleh sikap menggunakan teknologi dimana niat pelanggan akan mempengaruhi tingkat penggunaan teknologi oleh seorang pengguna [2]. Sikap positif pengguna terhadap suatu teknologi dapat memberikan niat dan perilaku yang positif pula pada teknologi tersebut. Salah satu bukti nyata dari sikap positif tersebut dapat berupa word of mouth. Word of mouth merupakan pujian, rekomendasi dan komentar pelanggan sekitar pengalaman mereka atas layanan jasa dan produk yang betul-betul memengaruhi keputusan pelanggan atau perilaku pembelian mereka [6]. Dengan memiliki behavioral intention yang baik, maka ecommerce dapat mencapai tujuan akhir mereka yaitu loyalitas pelanggan. Loyalitas pelanggan adalah How to earn it to keep. Bahwa loyalitas pelanggan cenderung lebih dekat dengan perilaku bukan sikap. Dengan demikian seorang pelanggan telah membeli dua atau tiga kali produk yang sama maka otomatis telah dimaksudkan sebagai pelanggan yang loyal [1]. Oleh karena itu, dengan adanya pemahaman yang baik terhadap perilaku konsumen akan memudahkan manajemen dalam upaya untuk mengembangkan produk atau jasanya sesuai kebutuhan dan keinginan konsumen.

Dari kesimpulan yang ditarik berdasarkan penelitian yang dilakukan oleh hanifah oktana putri yang melakukan penelitian tentang behavioral intention dari penggunaan e-commerce shopee di kalangan mahasiswa di fakultas tarbiyah dan keguruan UIN Arraniry yang menggunakan metode UTAUT 1 yang hanya mampu menjelaskan pengaruh terhadap behavioral intention sebesar $42 \%$. Penelitian ini membuktikan bahwa aplikasi shopee mampu memberikan kemudahan dan membantu dalam menyelesaikan transaksi jual beli dengan lebih cepat. Serta 
Vol. 3, No. 2, June 2021

p-ISSN: 2656-5935 http://journal-isi.org/index.php/isi

e-ISSN: 2656-4882

penggunaan aplikasi terebut dapat dipengaruhi oleh sesorang dan kondisi fasilitas [8]. Juga, penelitian yang dilakukan oleh Riezka dwifany dan Grace widijoko yang meneliti tentang individual interest to buy product at shopee yang mengadopsi model penelitian UTAUT 2 namun dimodifikasi tanpa menggunakan variabel moderator dan menemukan bahwa penelitian tersebut hanya mampu menjelaskan faktor yang mempengaruhi behavioral intention sebesar 54,6\% [4]. Penelitian ini menjelaskan bahwa behavioral intention dipengaruhi oleh tingkat efektifitas dan efisiensi, pengaruh lingkungan, perngaruh kondisi fasilitas, kesenangan yang didapat saat menggunakan aplikasi dan kebiasaan. Selain itu, penelitian dari Sutanto, dkk yang melakukan penelitian tentang faktor-faktor yang memengaruhi penerimaan dan penggunaan sistem informasi pengelolaan keuangan daerah (SIPKD) di kabupaten semarang dengan menggunakan model UTAUT 2 menunjukkan bahwa penelitian tersebut mampu memjelaskan faktor yang mempengaruhi behavioral intention hanya sebesar 41,4\% dan use behavior sebesar $45,7 \%$ [9]. Hasil penelitian ini menunjukkan bahwa semakin tinggi motivasi hedonis atau kesenangan menggunakan teknologi maka semakin tinggi niat untuk menggunakan sistem teknologi informasi dan juga kebiasaan (habit) dalam menggunakan SIPKD juga akan meningkatkan behavioral intention dan use behavior penggunaan aplikasi. Lalu dibantu dengan kondisi fasilitas yang semakin baik atau ideal akan memberikan dampak meningkatnya penggunaan..

\section{METODE PENELITIAN}

\subsection{Metode Analisis Data}

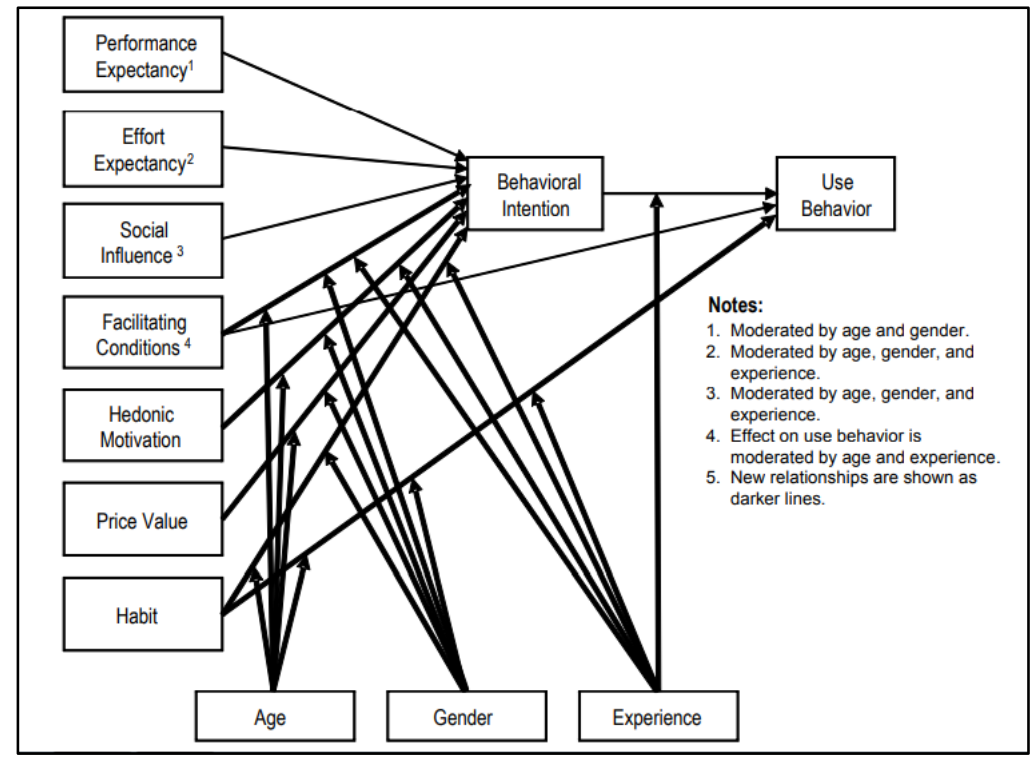


Vol. 3, No. 2, June 2021

p-ISSN: 2656-5935 http://journal-isi.org/index.php/isi

e-ISSN: 2656-4882

\section{Gambar 1. Model UTAUT 2 [Kesalahan! Sumber referensi tidak ditemukan.]}

Penelitian ini mengadaptasi model untuk menganalisis data yaitu Unified Theory of Acceptance and Use of Technology 2 (UTAUT 2). UTAUT merupakan salah satu model yang menggambarkan faktor-faktor penerimaan teknologi informasi oleh individu dengan mengukur behavioral intention dan use behavior-nya yang awalnya hanya memiliki empat variabel [12], namun sekarang telah dikembangkan kembali dengan tujuh variabel dan dilengkapi dengan variabel moderator. Berikut adalah penjelasan dari masing-masing variabel pada UTAUT 2 :

\section{Performance Expectancy}

Ventakes et al (2003) medefinisikan bahwa Performance Expectancy atau kinerja harapan sebagai tingkat dimana sesorang individu percaya bahwa dengan menggunakan sistem akan membantu dia dalam memperoleh keuntungan dalam kinerja [12]. Dalam hal ini dapat digambarkan seseorang yang terhubung ke internet mampu melakukan transaksi pembelian barang atau jasa dengan ponsel atau komputer mereka tanpa harus memakan waktu yang lama. Kemudahan tersebut akan sangat membantu kinerja dalam pekerjaan mereka.

2. Effort Expectancy

Ventakes et al (2003) menjelaskan bahwa Effort Expectancy atau harapan usaha merupakan tingkat kemudahan yang dirasakan seorang individu terkait dengan penggunaan sistem [Kesalahan! Sumber referensi tidak ditemukan.]. Artinya sistem tersebut mampu mengurangi usaha (tenaga dan waktu) pengguna. Venkatesh dan Davis (2000) mengatakan bahwa Kemudahan penggunaan teknologi informasi akan menimbulkan perasaan dalam diri seseorang bahwa sistem itu mempunyai kegunaan dan karenanya menimbulkan rasa yang nyaman bila bekerja dengan menggunakannya [Kesalahan! Sumber referensi tidak ditemukan.]. Contoh nya jika sebuah E-Commerce memiliki rancangan halaman muka yang baik, maka pengguna akan merasa nyaman dan mudah dalam melakukan transaksi jual beli secara terus menerus.

3. Social Influence

Ventakes et al (2003) mengartikan bahwa Social Influence atau pengaruh sosial adalah usaha yang dilakukan oleh seorang individu atau lebih didalam mengubah sebuah kepercayaan, persepsi dan tingkah laku orang lain [Kesalahan! Sumber referensi tidak ditemukan.]. Moore dan Benbasat (1991) menyatakan bahwa pada lingkungan tertentu, penggunaan teknologi informasi akan meningkatkan status (image) seseorang di dalam sistem sosial. Maka, semakin banyak dorongan sosial akan semakin besar pula keinginan seseorang untuk menggunakan teknologi [7]. Dalam hal ini dapat digambarkan jika seseorang yang memiliki pengalaman yang baik di sebuah E-Commerce, maka mereka dapat 
Vol. 3, No. 2, June 2021

p-ISSN: 2656-5935 http://journal-isi.org/index.php/isi

e-ISSN: 2656-4882

memperngaruhi lingkungan disekitar nya untuk melakukan transaksi jual beli yang sama dengan dia.

4. Facilitating Condition

Facilitating Condition didefinisikan sebagai sejauh mana seorang percaya bahwa infrastruktur organisasional dan teknikal tersedia untuk mendukung operasional sistem. Contohnya apakah perangkat untuk mengakses suatu E-Commerce telah tersedia atau tidak seperti ponsel atau komputer.

5. Hedonic Motivation

Menurut Brown dan Venkatesh (2005) Hedonic motivation didefinisikan sebagai kesenangan yang diperoleh dari penggunaan teknologi, hal ini telah terbukti berperan penting dalam penerimaan dan penggunaan teknologi [2]. Aplikasi yang dapat menawarkan kesenangan kepada pelanggan, memiliki kemungkinan yang besar untuk menarik minat pengguna. Secara umum, kesenangan dapat berupa kenyaman pelanggan ketika menggunakan aplikasi. Namun dalam penelitian ini, kesenangan yang dimaksud dapat berupa potongan harga, cashback dan juga gratis ongkir yang diberikan secara terus menerus.

6. Price Value

Dodds, et al (1991, dalam Venkatesh, at al 2012) mendefinisikan price value sebagai perspektif pelanggan dalam memilih antara manfaat yang didapatkan dari penggunaan sebuah teknologi dengan biaya yang dikeluarkan untuk menggunakan teknologi tersebut [Kesalahan! Sumber referensi tidak ditemukan.]. Price value dapat bernilai positif ketika manfaat yang didapat dari penggunaan teknologi bernilai lebih besar dari biaya yang dikeluarkan sehingga menimbulkan keinginan untuk terus menggunakan teknologi tersebut.

7. Habit

Menurut kamus besar bahasa Indonesia habit adalah pola untuk melakukan tanggapan terhadap situasi tertentu yang dipelajari oleh seorang individu dan yang dilakukannya secara berulang untuk hal yang sama. Definisi habit menurut ilmu psikologi merupakan rutinitas dari perilaku yang diulang secara teratur dan cenderung terjadi sadar. Artinya dalam hal ini, pengguna teknologi dapat menggunakan sebuah teknologi secara berulang dan teratur untuk tujuan tertentu. Sejalan dengan yang dikatakan oleh Venkatesh, at al (2012) bahwa habit berpengaruh terhadap penggunaan teknologi secara langsung karena kebiasaan yang dilakukan oleh pelanggan secara berulang [Kesalahan! Sumber referensi tidak ditemukan.].

\subsection{Metode Pengolahan Data}


Vol. 3, No. 2, June 2021

p-ISSN: 2656-5935 http://journal-isi.org/index.php/isi

e-ISSN: 2656-4882

Data pada penelitian ini dikumpulkan menggunakan kuesioner yang disebarkan secara online melalui media sosial kepada pengguna shopee di kota Palembang. Sampel penelitian adalah sebanyak 80 orang yang didapat dari perhitungan menggunakan rumus slovin dan menggunakan proporsi 100 terhadap populasi Infinite atau yang tidak dapat diketahui jumlah data empirisnya.

$$
\mathrm{n}=\frac{N}{1+N e^{2}}
$$

Pengelolahan data pada penelitian ini menggunakan pendekatan Structural Equation Model (SEM) berbasis Partial Least Square (PLS) dengan menggunakan aplikasi SmartPLS 3. SEM merupakan suatu metode analisis statistik multivarian sedangkan Partial Least Square disingkat PLS merupakan jenis analisis SEM yang berbasis komponen dengan sifat konstruk formatif. Pendekatan PLS secara khusus berguna juga untuk memprediksi variabel dependent dengan melibatkan sejumlah besar variabel independent. Pendekatan PLS dipilih karena dirasa tepat dan sesuai dengan karakteristik data penelitian yang sampel nya kurang dari 100 dan sejalan dengan tujuan penelitian yang ingin melihat pengaruh variabel yang ada pada model UTAUT terhadap behavioral intention.

Di dalam PLS terdapat 3 kegiatan secara bersamaan yang pertama adalah adalah mengukur nilai outer model. Pengujian outer model bertujuan untuk menguji validitas \& reliabilitas indikator dan variabel. Ketentuan dari pengujian outer model adalah harus memiliki indikator loading factor sebesar $>0,7$ dan dengan nilai AVE $>0,5$. Lalu untuk menentukan reliabilitas dengan nilai cronbach's alpha $>0.60$ dan nilai composite reliability $>0,7$. Setelah itu akan dilakukan uji Goodness of fit model (GoF) dengan menggunakan perhitungan $\mathrm{Q}^{2}$ predictive relevance dan juga effect size $\left(\mathrm{F}^{2}\right)$. Uji partial F-test dilakukan untuk menghitung besarnya efektivitas variabel bebas terhadap varibel terikat. 0 - 0,2 tergolong pada effect size lemah. 0,21 - 0,50 tergolong effect size modest. 0,51 - 1,00 tergolong effect size moderate dan >1,00 tergolong effect size kuat.

Langkah selanjutnya adalah melakukan uji $\mathrm{Q}^{2}$ predictive relevance. Jika $\mathrm{Q}^{2}$ bernilai $>$ 0 maka maka model tersebut dinyatakan predictive relevance. Dengan nilai $\mathrm{Q}^{2}$ sebesar 0,02 maka dapat dinyatakan predictive relevance lemah. Jika nilai $\mathrm{Q}^{2}$ sebesar 0,15 berarti model tersebut memiliki moderate predictive relevance dan jika $\mathrm{Q}^{2}$ bernilai 0,35 maka dinyatakan predictive relevance kuat. Pada pengujian GoF terdapat pula perhitungan standardized root mean residual (SRMR) yang harus bernilai $<0,10$ dan adjusted $\mathrm{R}$ yang bernilai antara $0-1$ dan dapat dikatakan baik jika nilai adjusted $\mathrm{R}$ diatas 0,5. Tahap terakhir pada PLS ini adalah pengujian inner model yang berguna untuk menguji positifitas dan signifikansi pengaruh dari variabel bebas terhadap variabel terikat dengan ketentuan jika $\mathrm{P}$ value $<0,05$ dan $\mathrm{T}$ value $>1,96$.

\subsection{Hipotesis Penelitian}


Vol. 3, No. 2, June 2021

p-ISSN: 2656-5935 http://journal-isi.org/index.php/isi e-ISSN: 2656-4882

Bedasarkan model UTAUT 2 yang diadaptasi dalam penelitian ini, maka hipotesis yang diuji pada penelitian ini dapat dilihat pada gambar berikut

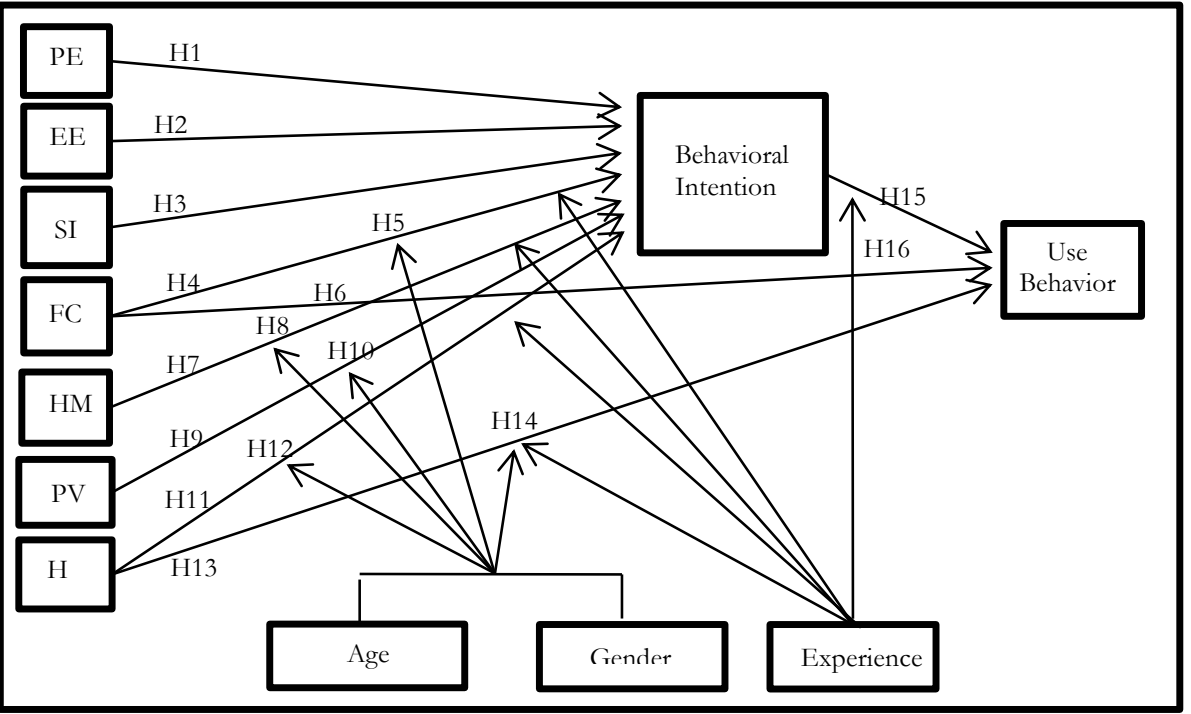

Gambar 2. Hipotesis penelitian

Berikut adalah penjabaran dari hipostesis pada penelitian ini:

1. $\mathrm{H}_{0}$ : Performance expectancy akan berpengaruh positif dan signifikan terhadap perilaku pengguna (behavioral intention) e-commerce shopee di kota Palembang $\mathrm{H}_{\mathrm{a}}$ : Performance expectancy tidak akan berpengaruh positif dan signifikan terhadap perilaku pengguna (behavioral intention) e-commerce shopee di kota Palembang

2. $\mathrm{H}_{0}$ : Effort Expectancy akan berpengaruh positif dan signifikan terhadap perilaku pelanggan (behavioral intention) e-commerce shopee di kota Palembang $\mathrm{H}_{\mathrm{a}}$ : Effort Expectancy tidak akan berpengaruh positif dan signifikan terhadap perilaku pelanggan (behavioral intention) e-commerce shopee di kota Palembang

3.

4. $\mathrm{H}_{0}$ : Social Influence akan berpengaruh positif dan signifikan terhadap perilaku pelanggan (behavioral intention) e-commerce shopee di kota Palembang

$\mathrm{H}_{\mathrm{a}}$ : Social Influence tidak akan berpengaruh positif dan signifikan terhadap perilaku pelanggan (behavioral intention) e-commerce shopee di kota Palembang 
Vol. 3, No. 2, June 2021

p-ISSN: 2656-5935 http://journal-isi.org/index.php/isi

e-ISSN: 2656-4882

5. $\mathrm{H}_{0}$ : Facilitating condition akan berpengaruh positif dan signifikan terhadap perilaku pelanggan (behavioral intention) e-commerce shopee di kota Palembang

$\mathrm{H}_{\mathrm{a}}$ : Facilitating condition tidak akan berpengaruh positif dan signifikan terhadap perilaku pelanggan (behavioral intention) e-commerce shopee di kota Palembang

6. $\mathrm{H}_{0}$ : Age, gender dan experience akan memoderatori pengaruh dari facilitating condition terhadap behavioral intention pelanggan e-commerce shopee di kota Palembang terkhusus nya kepada perempuan yang lebih tua dengan pengalaman yang minim

Ha : Age, gender dan experience tidak akan memoderatori pengaruh dari facilitating condition terhadap behavioral intention pelanggan ecommerce shopee di kota Palembang terkhusus nya kepada perempuan yang lebih tua dengan pengalaman yang minim.

7. $\mathrm{H}_{0}$ : Facilitating condition akan berpengaruh positif dan signifikan terhadap use behavior e-commerce shopee di kota Palembang

$\mathrm{H}_{\mathrm{a}}$ : Facilitating condition tidak akan berpengaruh positif dan signifikan terhadap use behavior e-commerce shopee di kota Palembang

8. $\mathrm{H}_{0}$ : Hedonic motivation akan berpengaruh positif dan signifikan terhadap perilaku pelanggan (behavioral intention) e-commerce shopee di kota Palembang

$\mathrm{H}_{\mathrm{a}}$ : Hedonic motivation tidak akan berpengaruh positif dan signifikan terhadap perilaku pelanggan (behavioral intention) e-commerce shopee di kota Palembang

9. $\mathrm{H}_{0}$ : Age, gender dan experience akan memoderatori pengaruh hedonic motivation terhadap behavioral intention pelanggan e-commerce shopee di kota Palembang yang mana akan memiliki efek yang lebih besar kepada lakilaki muda dengan pengalaman yang minim

$\mathrm{H}_{\mathrm{a}}$ : Age, gender dan experience tidak akan memoderatori pengaruh hedonic motivation terhadap behavioral intention pelanggan e-commerce shopee di kota Palembang yang mana akan memiliki efek yang lebih besar kepada lakilaki muda dengan pengalaman yang minim

10. $\mathrm{H}_{0}$ : Price value akan berpengaruh positif dan signifikan terhadap perilaku pelanggan (behavioral intention) e-commerce shopee di kota Palembang $\mathrm{H}_{\mathrm{a}}$ : Price value tidak akan berpengaruh positif dan signifikan terhadap perilaku pelanggan (behavioral intention) e-commerce shopee di kota Palembang 
11. $\mathrm{H}_{0}$ : Age dan gender akan memoderatori pengaruh price value terhadap behavioral intention pelanggan e-commerce shopee di kota Palembang yang mana akan memiliki efek yang lebih besar kepada perempuan yang berusia lebih tua.

$\mathrm{H}_{\mathrm{a}}$ : Age dan gender tidak akan memoderatori pengaruh price value terhadap behavioral intention pelanggan e-commerce shopee di kota Palembang yang mana akan memiliki efek yang lebih besar kepada perempuan yang berusia lebih tua.

12. $\mathrm{H}_{0}$ : Habit akan berpengaruh positif dan signifikan terhadap perilaku pelanggan (behavioral intention) e-commerce shopee di kota Palembang $\mathrm{H}_{\mathrm{a}}$ : Habit tidak akan berpengaruh positif dan signifikan terhadap perilaku pelanggan (behavioral intention) e-commerce shopee di kota Palembang

13. $\mathrm{H}_{0}:$ Age, gender dan experience akan memoderatori pengaruh babit terhadap behavioral intention pelanggan e-commerce shopee di kota Palembang yang mana akan memiliki efek yang lebih besar kepada laki-laki berusia lebih tua dengan pengalaman yang cukup

$\mathrm{H}_{\mathrm{a}}$ : Age, gender dan experience tidak akan memoderatori pengaruh babit terhadap behavioral intention pelanggan e-commerce shopee di kota Palembang yang mana akan memiliki efek yang lebih besar kepada laki-laki berusia lebih tua dengan pengalaman yang cukup

14. $\mathrm{H}_{0}$ : Habit akan berpengaruh positif dan signifikan terhadap use behavior ecommerce shopee di kota Palembang

$\mathrm{H}_{\mathrm{a}}$ : Habit tidak akan berpengaruh positif dan signifikan terhadap use behavior e-commerce shopee di kota Palembang

15. $\mathrm{H}_{0}:$ Age, gender dan experience akan memoderatori pengaruh habit terhadap use behavior pelanggan e-commerce shopee di kota Palembang yang mana akan memiliki efek yang lebih besar kepada laki-laki berusia lebih tua dengan pengalaman yang cukup

$\mathrm{H}_{\mathrm{a}}$ : Age, gender dan experience tidak akan memoderatori pengaruh babit terhadap use behavior pelanggan e-commerce shopee di kota Palembang yang mana akan memiliki efek yang lebih besar kepada laki-laki berusia lebih tua dengan pengalaman yang cukup

16. $\mathrm{H}_{0}$ : Behavioral intention akan berpengaruh positif dan signifikan terhadap use behavior e-commerce shopee di kota Palembang

$\mathrm{H}_{\mathrm{a}}$ : Behavioral intention tidak akan berpengaruh positif dan signifikan terhadap use behavior e-commerce shopee di kota Palembang 
Vol. 3, No. 2, June 2021

p-ISSN: 2656-5935 http://journal-isi.org/index.php/isi

e-ISSN: 2656-4882

17. $\mathrm{H}_{0}$ : Experience akan memoderasi pengaruh behavioral intention terhadap use behavior yang pengaruhnya akan lebih kuat bagi pengguna dengan pengalaman yang kurang

$\mathrm{H}_{\mathrm{a}}$ : Experience tidak akan memoderasi pengaruh behavioral intention terhadap use behavior yang pengaruhnya akan lebih kuat bagi pengguna dengan pengalaman yang kurang

\section{HASIL DAN PEMBAHASAN}

Dengan menggunakan aplikasi SmartPLS 3 yang didasari dari model penelitian UTAUT 2 dan diolah dari data kuesioner yang telah didapat maka berikut adalah diagram hasil yang telah dilengkapi dengan angka hasil uji outer model.

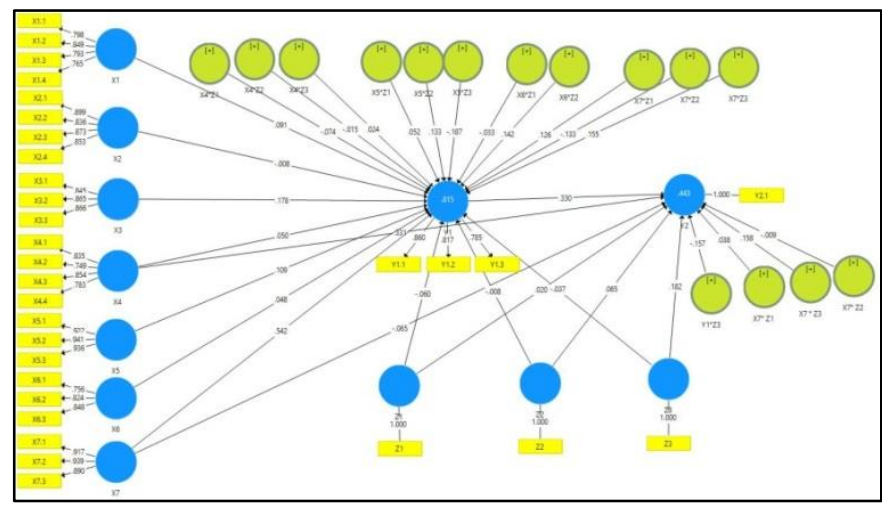

Gambar 3. Diagram hasil analisa

\subsection{Karakteristik Responden}

Adapun yang menjadi karakteristik dari responden pada penelitian ini adalah jenis kelamin, usia dan juga tingkat pengalaman dalam menggunakan aplikasi shopee yangmana karakteristik ini juga menjadi variabel moderator dalam model UTAUT 2.

A. Jenis Kelamin 
Vol. 3, No. 2, June 2021

p-ISSN: 2656-5935 http://journal-isi.org/index.php/isi e-ISSN: 2656-4882

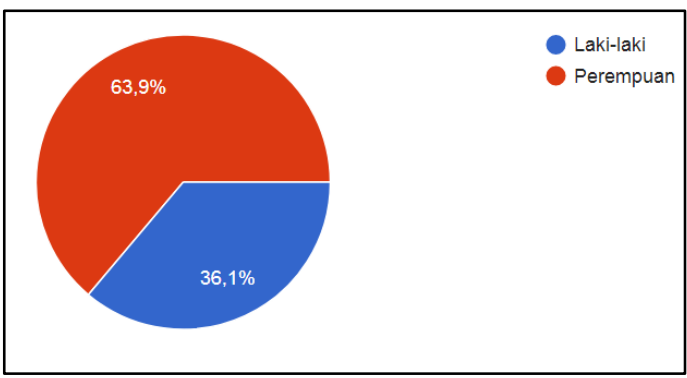

Gambar 4. Jenis Kelamin Responden

Berdasarkan hasil pengolahan data, dari total 83 responden terdapat 63,9\% responden dengan jenis kelamin perempuan atau sebanyak 53 orang dan 36,1\% atau 30 orang responden dengan jenis kelamin laki-laki. Yang artinya perempuan mendominasi penggunaan shopee dikota Palembang.

B. Usia

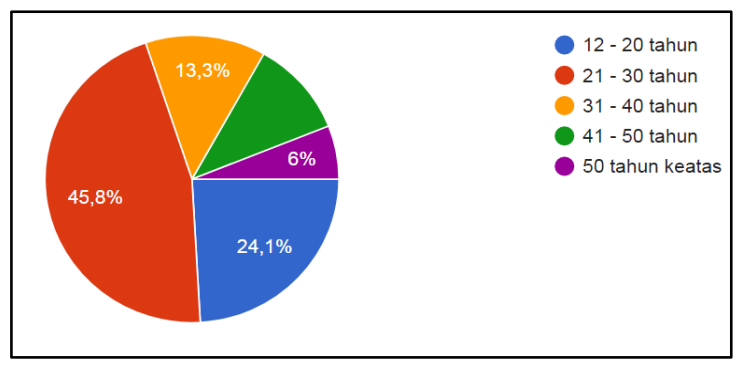

Gambar 5. Usia Responden

Dari hasil pengolahan data, terdapat $24,1 \%$ atau 20 responden yang berusia $12-20$ tahun. 45,8\% setara dengan 38 responden yang berusia $21-30$ tahun. 13,3\% atau 11 responden dengan usia 31-40 tahun. Dengan usia 41-50 tahun sebanyak 10,8\% atau 9 orang dan sisanya 6\% atau 5 orang dengan usia 50 tahun keatas. Artinya dapat disimpulkan bahwa mayoritas pengguna aplikasi shopee di kota Palembang adalah yang berumur 21-30 tahun. Selanjutnya disusul oleh kalangan di umur 1220 tahun.

C. Tingkat Penggunaan 
Vol. 3, No. 2, June 2021

p-ISSN: 2656-5935 http://journal-isi.org/index.php/isi e-ISSN: 2656-4882

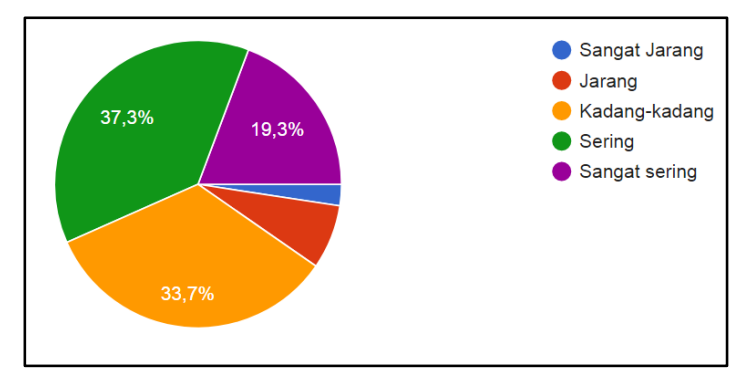

Gambar 6. Tingkat penggunaan Responden

Dapat dilihat dari diagram diatas bahwa sebanyak $19.3 \%$ atau 16 orang menyatakan sangat sering menggunakan aplikasi shopee. Sebanyak $37.3 \%$ atau setara dengan 31 orang mengatakan sering menggunakan aplikasi shopee. 33,7\% atau 28 orang mengatakan kadang-kadang menggunakan aplikasi shopee. 7,2\% atau sebanyak 6 orang dalam penelitian ini jarang menggunakan aplikasi shopee dan sebanyak 2,4\% atau 2 orang menyatakan sangat jarang menggunakan aplikasi shopee.

\subsection{Uji Validitas}

Uji validitas dilakukan dengan melihat nilai pada loading factor yang harus bernilai $>0,5$. Jika terdapat item variabel yang bernilai lebih dari 0,5 maka item tersebut harus di hapus (dropped). Pengujian validitas ini dibedakan menjadi dua yaitu uji validitas konvergen dan uji validitas diskriminan. Dimana uji validitas konvergen akan dilihat dari besaran nilai loading factor sementara uji validitas diskriminan dilihat dari besaran nilai average variance extracted (AVE). Dimana nilai AVE harus lebih tinggi daripada korelasi yang melibatkan variabel bebas lain.

A. Uji Validitas Konvergen 
Journal of Information Systems and Informatics

Vol. 3, No. 2, June 2021

p-ISSN: 2656-5935 http://journal-isi.org/index.php/isi e-ISSN: 2656-4882

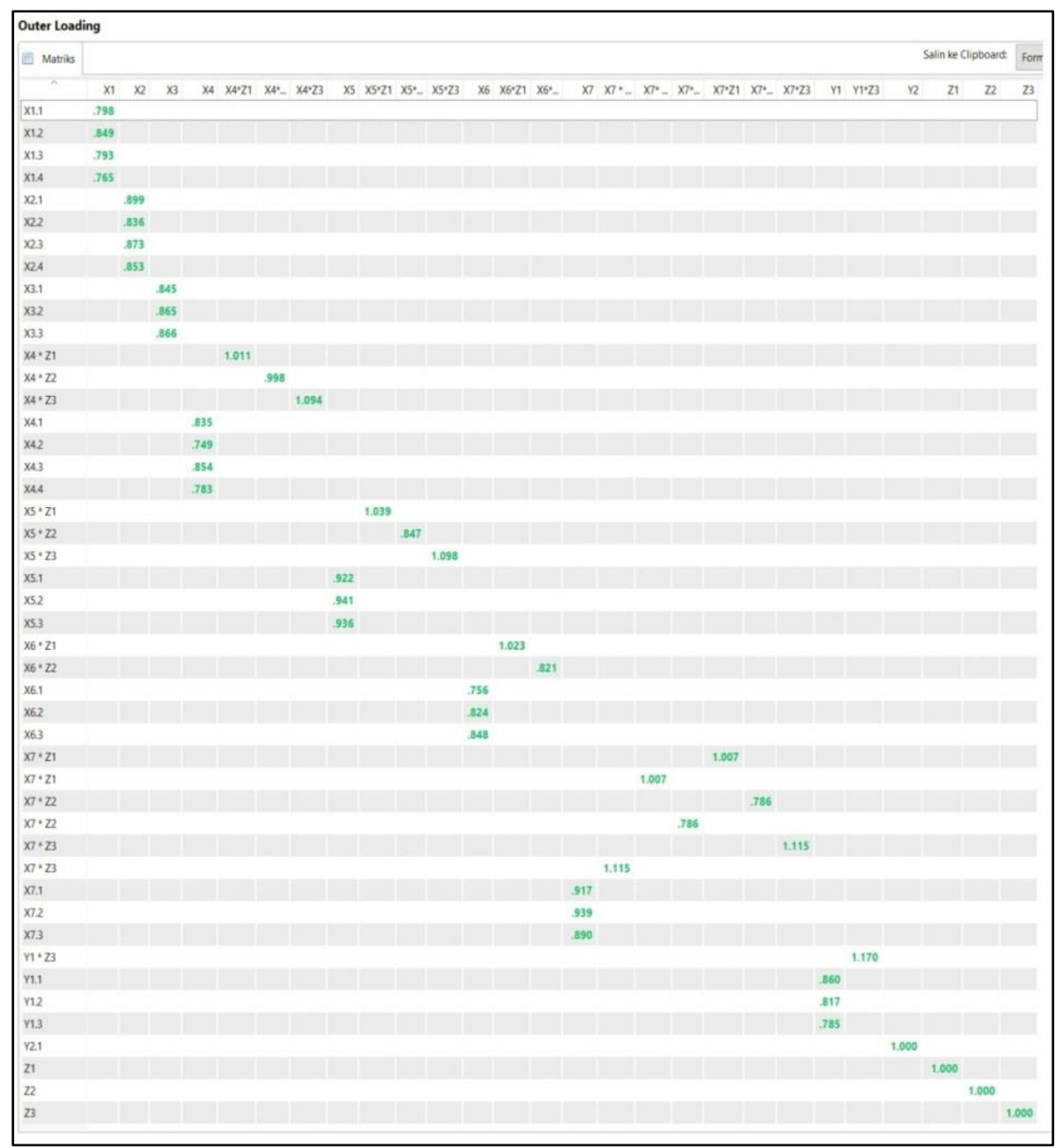

Gambar 7. Hasil uji validitas konvergen

Dapat dilihat dari tabel diatas bahwa dari seluruh item variabel bernilai lebih dari 0,5 dan ditandai dengan angka berwarna hijau pada aplikasi SmartPLS. Hal ini berarti variabel dari penelitian ini valid dan setiap item variabel bebas pada penelitian ini dapat dipahami oleh responden dengan cara yang sama yang diinginkan oleh peneliti.

B. Uji Validitas Konvergen 
Vol. 3, No. 2, June 2021

p-ISSN: 2656-5935 http://journal-isi.org/index.php/isi e-ISSN: 2656-4882

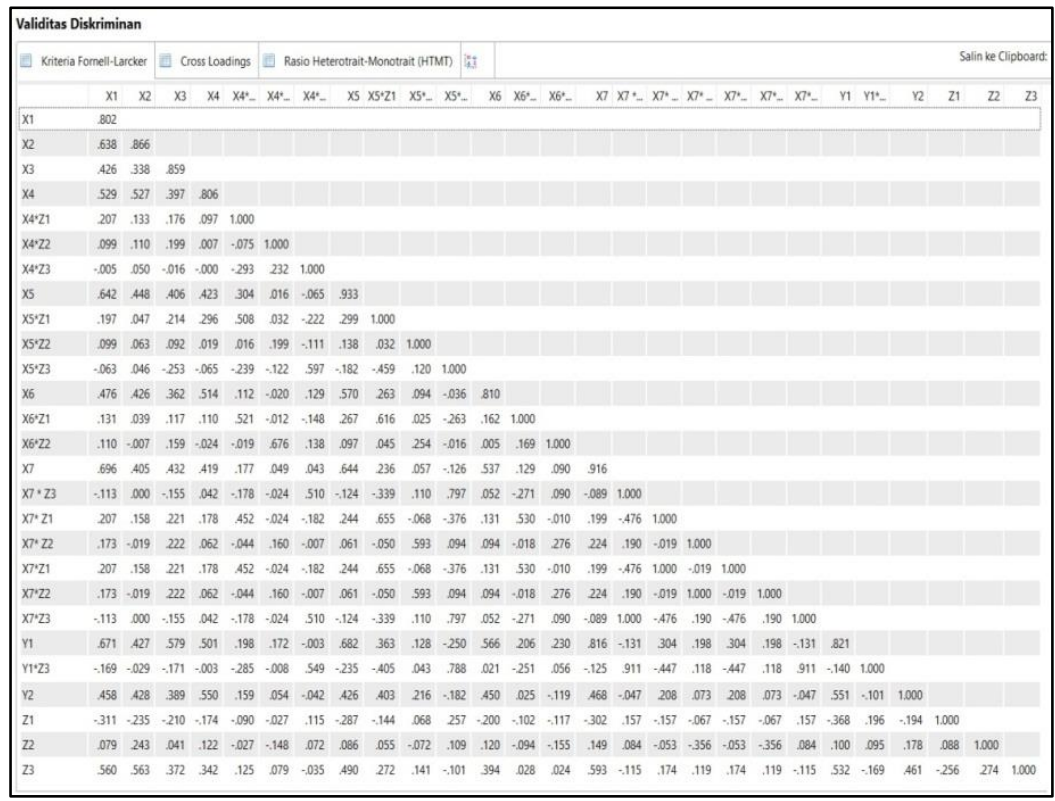

Gambar 8. Hasil uji validitas diskriminan

Pengujian validitas diskriminan juga telah memenuhi syarat yang telah ditentukan karena nilai AVE pada tabel di bawah ini menunjukkan nilai tertinggi dibandingkan korelasi lain yang melibatkan variabel bebas tersebut. Artinya item-item pada setiap variabel bebas tidak dikacaukan oleh responden yang menjawab kuesioner berdasarkan pernyataan item pada variabel lain.

\subsection{Uji Reliabilitas}

Uji reliabilitas dilakukan untuk mengukur tingkat konsistensi kuesioner sehingga data yang diperoleh dapat dipercaya untuk menentukan informasi dan mengambil kesimpulan. Untuk mengukur reliabilitas kuesioner penelitian ini, di gunakan dua pengukuran yaitu rumus cronbach's alpha dan reliabilitas komposit. Dimana nilai cronbach's alpha harus $>0.60$ dan nilai composite reliability harus $>0,7$ serta nilai average variance extracted (AVE) harus mencapai 0,50. 


\section{Journal of Information Systems and Informatics}

Vol. 3, No. 2, June 2021

p-ISSN: 2656-5935 http://journal-isi.org/index.php/isi e-ISSN: 2656-4882

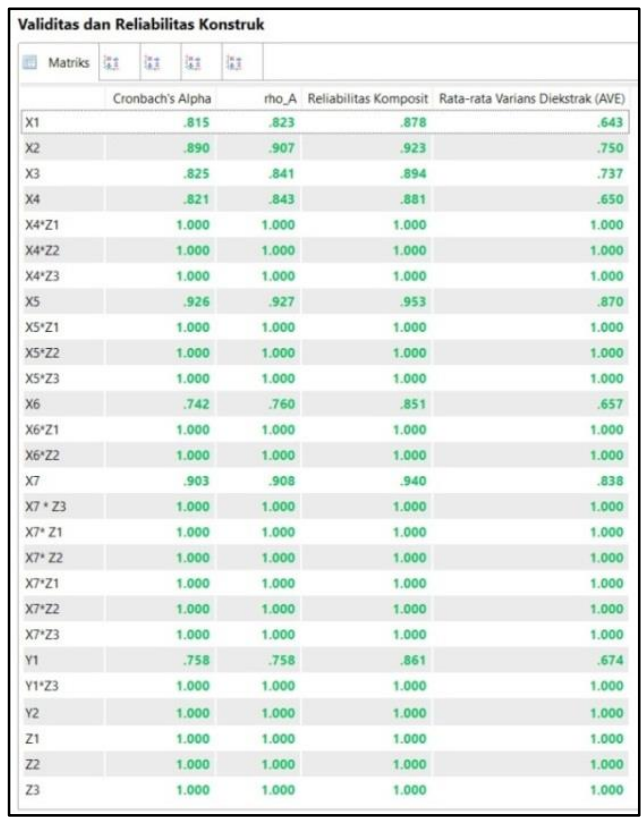

Gambar 9. Hasil uji reliabilitas

Berdasarkan tabel diatas, dapat dilihat bahwa nilai cronbach's alpha, reliabilitas komposit dan AVE setiap variabel telah memenuhi standar yang ada yaitu ketika variabel memiliki nilai cronbach's alpha $>0.60$, nilai composite reliability $>0,7$ dan nilai AVE yang telah memenuhi syarat yaitu $>0,50$. Sehingga dapat dikatakan variabel dari penelitian ini reliabel. Yang ditandai pada aplikasi SmartPLS dengan angka berwarna hijau, jika angka berwarna merah hal tersebut berarti terdapat kejanggalan pada data tersebut.

\subsection{Uji Goodness of fit model (GoF)}

Uji Goodness of fit model (GoF) termasuk tahap awal dalam uji inner model sebelum dilakukan teknik bootsrapping yang berguna untuk mementukan hipotesis dapat diterima atau tidak dengan menggunakan $\mathrm{T}$ value dan $\mathrm{P}$ value.

Uji R Square.

\begin{tabular}{|c|c|c|c|}
\hline \multicolumn{4}{|l|}{ R Square } \\
\hline \multirow[t]{2}{*}{ Matriks } & 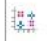 & 摸革 & \\
\hline & & R Square & Adjusted R Square \\
\hline Y1 & & .815 & .751 \\
\hline Y2 & & .443 & .365 \\
\hline
\end{tabular}

Gambar 10. Hasil Uji R Square 
Vol. 3, No. 2, June 2021

p-ISSN: 2656-5935 http://journal-isi.org/index.php/isi

e-ISSN: 2656-4882

Hasilnya nilai adjusted $\mathrm{R}$ square terhadap behavioral intention (Y1) adalah sebesar 0,751. Artinya bahwa kontribusi dari variabel performance expectancy, effort expectancy, social influence, facilitating condition, Hedonic Motivation, Price Value dan Habit yang dimoderatori oleh Age, gender dan experience mengambil andil sebesar 75\% terhadap behavioral intention pelanggan shopee di kota Palembang. Sisa nya sebesar 25\% akan dipengaruhi oleh variabel atau faktor lain.

Sementara untuk use behavior dengan nilai adjusted $\mathrm{R}$ square terhadap use behavior (Y2) adalah sebesar 0,365. Artinya variabel performance expectancy, effort expectancy, social influence, facilitating conditions, Hedonic Motivation, Price Value, Habit dan behavioral intention yang dimoderatori oleh Age, gender dan experience berpengaruh sebesar 36\% yang sisa nya sebesar 64\% akan dipengaruhi oleh variabel lain diluar penelitian.

\section{A. Uji F Square}

F square dilakukan untuk mengetahui seberapa besar pengaruh variabel bebas terhadap variabel terikat.

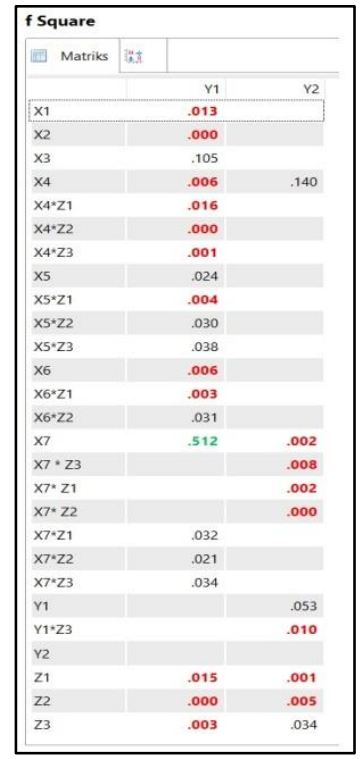

Gambar 11. Hasil Uji F Square

Tabel diatas menjelaskan bahwa untuk variabel terikat behavioral intention (Y1), variabel Habit (X7) memiliki persentase yang paling besar yakni 0,51 yang tergolong dalam kategori effect size menengah. Selanjutnya disusul oleh variabel Social Influence (X3) yaitu sebesar 0,105 yang tergolong kategori effect size lemah. Variabel Performance expectancy (X1) dengan nilai F square sebesar 0,013 yang 
Vol. 3, No. 2, June 2021

p-ISSN: 2656-5935 http://journal-isi.org/index.php/isi e-ISSN: 2656-4882

artinya memiliki efek sangat lemah. Sama halnya dengan effort expectancy (X2) yang memiliki nilai $\mathrm{F}$ square sebesar 0,000 yang artinya tidak memiliki pengaruh sama sekali. Ada facilitating condition (X4) yang memiliki nilai sebesar 0,006 terhadap behavioral intention. Lalu Hedonic Motivation (X5) dengan F square sebesar 0,024. Yang terakhir variabel Price Value (X6) dengan nilai sebesar 0,006 yang artinya memiliki pengaruh yang sangat lemah.

Lalu untuk variabel use behavior (Y2), variabel yang paling memiliki pengaruh adalah variabel facilitating condition (X4) dengan angka sebesar 0,140 yang tergolong pada effect size lemah. Disusul oleh variabel behavioral intention (Y1) dengan nilai 0,053 dan habit (X7) dengan nilai 0,02 yang memiliki effect size lemah.

B. $\mathrm{Uji}^{2} \mathrm{Q}^{2}$ predictive relevance

$\mathrm{Q}^{2}$ predictive relevance berfungsi untuk memvalidasi model penelitian. Nilai $\mathrm{Q}^{2}$ predictive relevance didaptkan pada tahap blindfolding pada aplikasi Smartpls. Jika nilai $\mathrm{Q}^{2}>0$ maka akan dinyatakan predictive relevance.

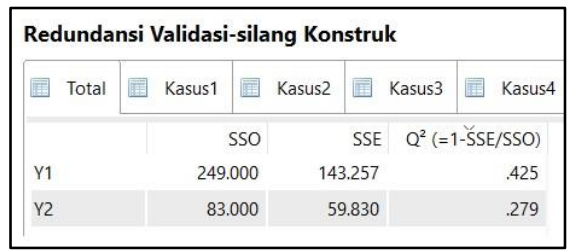

Gambar 12. Hasil uji $\mathrm{Q}^{2}$ predictive relevance

Untuk nilai $\mathrm{Q}^{2}$ terhadap behavioral intention (Y1) pada penelitian ini adalah sebesar 0,425 yang artinya tergolong pada predictive relevance kuat. Sementara untuk use behavior (Y2) nilai $\mathrm{Q}^{2}$ adalah 0,279 yang tergolong pada predictive relevance moderate atau menengah. Pada penelitian ini seluruh variabel terikat Y1 dinyatakan predictive relevance kuat dan positif sehingga dapat dinyatakan valid dan juga Y2 bernilai predictive relevance menengah serta positif. Kedua variabel tersebut dinyatakan valid dan predictive relevance.

\section{Uji Fit Model}

Nilai Q2 predictive relevance tersebut akan didukung dengan nilai goodness of fit melalui standardized root mean residual (SRMR) yang harus bernilai $<0,10$. Dapat dilihat dari tabel dibawah ini bahwa nilai SRMR dari model penelitian ini adalah sebesar 0,82 yang berarti penelitian ini layak atau memiliki fit model terhadap data yang ada. 
Vol. 3, No. 2, June 2021

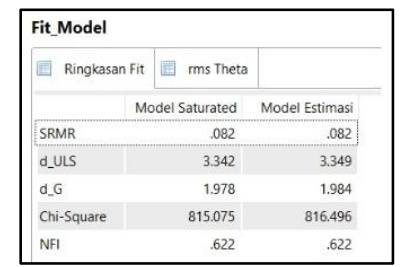

Gambar 13. Hasil uji Fit model

\subsection{Uji Hipostesis}

Hipotesis penelitian ini dapat diterima atau ditolak dengan menggunakan uji signifikansi dengan hasil analisis yang didapat dari tabel path coeficient dan jika $\mathrm{P}$ value $<0,05$ dan T value $>1,96$ maka dapat dinyatakan signifikan yang berarti hipotesis diterima. Pada tahap ini akan dilihat pengaruh yang ditimbulkan oleh variabel bebas (dependent) terhadap variabel terikat (independent) yang akan dimoderatori oleh age, gender dan experience.

\begin{tabular}{|c|c|c|c|c|c|c|c|c|}
\hline \multicolumn{9}{|c|}{ Koefisien Jalur } \\
\hline \multirow[t]{2}{*}{ Mean, STDE } & EV, T-Values, P-Valu & Ives & Keyakinan Inter & & Keyakinan Interva & al Bias-Dikoreksi & Sampel & \\
\hline & Sampel Asli (O) & Rata-r: & rata Sampel (M) & Stand & dar Deviasi (STDEV) & T Statistik (1) O/ST & TDEV D & P Values \\
\hline $\mathrm{X}_{1} \rightarrow \mathrm{Y}_{1}$ & .091 & & .070 & & .106 & & .861 & .390 \\
\hline$X_{2} \rightarrow y_{1}$ & .008 & & .011 & & .090 & & .087 & .930 \\
\hline$X_{3} \rightarrow Y_{1}$ & .178 & & .194 & & .090 & & 1.985 & .048 \\
\hline$X_{4} \rightarrow V_{1}$ & .050 & & .050 & & .992 & & .539 & .590 \\
\hline$x 4 \rightarrow 12$ & .331 & & .324 & & .120 & & 2762 & .006 \\
\hline $\mathrm{X} 4 \cdot \mathrm{Z} 1$ - $\mathrm{Y} 1$ & .074 & & -.081 & & .996 & & .772 & .440 \\
\hline$X 4^{*} \mathrm{Z2}->\mathrm{Y1}$ & .015 & & .030 & & .106 & & .143 & .886 \\
\hline$X 4^{*} Z 3 \rightarrow Y Y_{1}$ & .024 & & .036 & & .115 & & 209 & .835 \\
\hline$X_{5} \gg Y_{1}$ & .109 & & .123 & & .104 & & 1.051 & .294 \\
\hline$X 5 \bullet Z 1->Y_{1}$ & .052 & & .057 & & .121 & & .424 & .671 \\
\hline $\mathrm{X} 5 \cdot \mathrm{Z2} \rightarrow \mathrm{Y} 1$ & .133 & & .128 & & 107 & & 1.249 & .212 \\
\hline $\mathrm{X} 5 \cdot \mathrm{Z} 3 \rightarrow \mathrm{Y} 1$ & -.187 & & -.193 & & .156 & & 1.196 & .232 \\
\hline$X 6 \mapsto Y_{1}$ & .048 & & .041 & & .100 & & .476 & .634 \\
\hline$X 6 * Z 1$ - Y 1 & .033 & & .018 & & 108 & & 301 & .763 \\
\hline$X 6: Z 2->Y 1$ & .142 & & .163 & & .115 & & 1.241 & .215 \\
\hline$X_{7} \gg Y_{1}$ & .542 & & .531 & & .114 & & 4.755 & .000 \\
\hline$x 7 \rightarrow>12$ & .065 & & -.063 & & .177 & & .367 & .714 \\
\hline$x 7 \cdot Z 3 \rightarrow 12$ & .158 & & .179 & & .213 & & .740 & .459 \\
\hline$x 7 * Z 1 \rightarrow Y 2$ & .038 & & .037 & & .087 & & .440 & .660 \\
\hline $\mathrm{X} 7 \cdot \mathrm{Z2} \rightarrow \mathrm{YZ}$ & .009 & & -011 & & .113 & & .078 & 938 \\
\hline$x 7 \cdot Z_{1}>Y_{1}$ & .126 & & .119 & & 107 & & 1.182 & .238 \\
\hline$X 7 \cdot Z_{2}->Y_{1}$ & -.133 & & -.125 & & .137 & & .969 & .333 \\
\hline $\mathrm{X} 7 * \mathrm{ZZ} \rightarrow>\mathrm{Y}_{1}$ & .155 & & .152 & & .153 & & 1.013 & .312 \\
\hline$V_{1} \rightarrow V_{2}$ & 330 & & .336 & & .186 & & 1.773 & .077 \\
\hline $\mathrm{Y} 1 \cdot \mathrm{Z3} \rightarrow \mathrm{Y2}$ & -.157 & & - 177 & & 189 & & .831 & .406 \\
\hline $\mathrm{Z1} \rightarrow \mathrm{Y1}$ & .060 & & -.057 & & .067 & & .905 & .366 \\
\hline$Z 1 \rightarrow>12$ & .020 & & .015 & & .102 & & .195 & .845 \\
\hline $\mathrm{Z2} \rightarrow \mathrm{Yr} 1$ & .008 & & .004 & & .080 & & .097 & .923 \\
\hline$Z 2 \rightarrow Y 2$ & .065 & & .062 & & .108 & & .600 & .549 \\
\hline $\mathrm{ZZ} \leadsto \mathrm{Yr} 1$ & .037 & & .041 & & .110 & & .332 & .740 \\
\hline$Z 3 \rightarrow>12$ & . 182 & & .183 & & .096 & & 1.887 & .060 \\
\hline
\end{tabular}

Gambar 14. Hasil uji hipotesis

Berikut adalah hasil dari interpretasi data dengan metode analisis PLS pada penelitian ini : 
1. HO : Performance expectancy akan berpengarub positif dan signifikan terhadap perilaku pengguna (behavioral intention) e-commerce shopee di kota Palembang

$H a$ : Performance expectancy tidak akan berpengaruh positif dan signifikan terhadap perilaku pengguna (behavioral intention) e-commerce shopee di kota Palembang

Pada hasil pengujian statistik yang dilakukan terhadap 83 data responden, maka hasil dari perhitungannya menyatakan bahwa untuk variabel performance expectancy (X1) memiliki nilai original sample (O) sebesar 0,91 yang bernilai positif. Berarti variabel bernilai positif terhadap behavioral intention. Namun, $\mathrm{T}$ value-nya menujukkan nilai 0,861 dan $\mathrm{P}$ value yang bernilai 0,390 yang mana tidak memenuhi standar yang sudah ditetapkan yakni $\mathrm{P}$ value harus $<0,05$ dan T value $>1,96$. Maka, dapat disimpulkan bahwa performance expectancy tidak berpengaruh dengan signifikan terhadap behavioral intention sehingga hipotesis 0 ditolak dan hipotesis a diterima $\mathbf{( \mathbf { H } _ { 0 }}$ : ditolak, $\mathbf{H}_{\mathbf{a}}$ : diterima). Dapat dilihat pula pada hasil uji $\mathrm{F}$ square dimana tingkat efektivitas variabel performance expectancy hanya sebesar 0,013 yang mana tergolong pada effect size lemah dan hamper tidak memiliki efektivitas terhadap behavioral intention. Hal ini menunjukkan bahwa produktivitas dan efektivitas dari pekerjaan masyarakat kota Palembang terkhususnya yang menggunakan aplikasi shopee, tidak tergantung pada aktivitas atau transaksi jual beli melalui shopee. Dalam kata lain dapat diartikan bahwa masyarakat kota Palembang tidak ketergantungan kepada aplikasi shopee untuk membantu pekerjaan mereka dalam hal jual beli barang maupun jasa.

2. $\mathrm{H}_{0}$ : Effort Expectancy akan berpengaruh positif dan signifikan terhadap perilaku pelanggan (behavioral intention) e-commerce shopee di kota Palembang

$\mathrm{H}_{\mathrm{a}}$ : Effort Expectancy tidak akan berpengaruh positif dan signifikan terhadap perilaku pelanggan (behavioral intention) e-commerce shopee di kota Palembang

Nilai yang dimiliki variabel effort expectancy untuk original sample adalah sebesar 0,008 dan bernilai negatif. Lalu memiliki T value senilai 0,087 dan $\mathrm{P}$ value sebesar 0,930. Angka-angka tersebut sangat jauh dari ketetapan yang ada. Jadi, dapat di simpulkan bahwa effort expectancy tidak memiliki pengaruh terhadap behavioral intention sehingga hipotesis 0 ditolak dan hipotesis a diterima $\left(\mathbf{H}_{\mathbf{0}}\right.$ : ditolak, $\mathbf{H}_{\mathrm{a}}$ : diterima). Nilai $\mathrm{F}$ square yang telah didapat juga mendukung ditolaknya hipotesis ini. Dari hasil uji $\mathrm{F}$ square menunjukkan bahwa variabel effort expectancy sama sekali tidak memiliki efektivitas terhadap variabel terikat yakni behavioral intention dengan nilai sebesar 0,000 . 
Vol. 3, No. 2, June 2021

p-ISSN: 2656-5935 http://journal-isi.org/index.php/isi e-ISSN: 2656-4882

3. $\mathrm{H}_{0}$ : Social Influence akan berpengaruh positif dan signifikan terhadap perilaku pelanggan (behavioral intention) e-commerce shopee di kota Palembang

$\mathrm{H}_{\mathrm{a}}$ : Social Influence tidak akan berpengaruh positif dan signifikan terhadap perilaku pelanggan (behavioral intention) e-commerce shopee di kota Palembang

Hipotesis 0 dinyatakan dapat diterima karena memiliki nilai original sample (O) 0,178 yang bernilai positif. Lalu variabel social influence memiliki nilai T value sebesar 1,985 dan $\mathrm{P}$ value sebesar 0,048 yang mana angka tersebut memenuhi syarat yang telah ditetapkan yaitu $\mathrm{P}$ value harus $<0,05$ dan $\mathrm{T}$ value $>1,96$. Sehingga pada penelitian ini variabel Social Influence berpengaruh positif dan signifikan terhadap behavioral intention $\mathbf{( H}_{\mathbf{0}}$ : diterima $\mathbf{H}_{\mathbf{a}}$ : ditolak). Besaran pengaruh atau efektivitas dari social influence juga memperkuat hipotesisi ini. Dapat dilihat dari hasil uji $\mathrm{F}$ square dimana hasilnya menunjukkan bahwa variabel social influence memiliki effect size sebesar 0,105 yakni lebih unggul dari dua variabel sebelumnya. Hal ini menunjukkan bahwa memang variabel social influence memiliki pengaruh terhadap behavioral intention pengguna shopee di kota Palembang yang dapat berupa dorongan sosial atau testimonial yang baik dari orang sekitar.

4. $\mathrm{H}_{0}$ : Facilitating condition akan berpengaruh positif dan signifikan terhadap perilaku pelanggan (behavioral intention) e-commerce shopee di kota Palembang

$\mathrm{H}_{\mathrm{a}}$ : Facilitating condition tidak akan berpengaruh positif dan signifikan terhadap perilaku pelanggan (behavioral intention) e-commerce shopee di kota Palembang

Untuk variabel facilitating condition dapat dilihat pada tabel Path Coefficient bahwa nilai dari original sampel-nya adalah 0,050 yang bernilai positif. Lalu memiliki $\mathrm{T}$ value 0,539 serta $\mathrm{P}$ value 0,590 . Artinya variabel facilitating condition memiliki pengaruh positif namun tidak signifikan terhadap behavioral intention. Sehingga sehingga hipotesis 0 ditolak dan hipotesis a diterima ( $\mathbf{H}_{\mathbf{0}}$ : ditolak, $\mathbf{H}_{\mathbf{a}}$ : diterima). Sejalan dengan penelitian yang dilakukan oleh An Liping, dkk (2016) juga menyatakan bahwa facilitating condition tidak memiliki pengaruh terhadap online shopping intention. Tidak hanya itu, ditolaknya hipotesis ini juga didukung dengan angka dari tabel F square yang menyebutkan bahwa variabel facilitating condition hanya memiliki efektivitas sebesar 0,006 terhadap behavioral intention yang tergolong pada effect size lemah dan hamper tidak memiliki pengaruh. Sehingga dapat disimpulkan berdasarkan hasil uji hipotesis dalam penelitian ini bahwa infrastruktur dan fasilitias yang terdapat pada aplikasi shopee tidak sepenuhnya mempengaruhi behavioral intention pengguna. 
5. $\mathrm{H}_{0}$ : Age, gender dan experience akan memoderatori pengaruh dari facilitating condition terhadap behavioral intention pelanggan e-commerce shopee di kota Palembang terkhusus nya kepada perempuan yang lebih tua dengan pengalaman yang minim

$\mathrm{H}_{\mathrm{a}}$ : Age, gender dan experience tidak akan memoderatori pengaruh dari facilitating condition terhadap behavioral intention pelanggan e-commerce shopee di kota Palembang terkhusus nya kepada perempuan yang lebih tua dengan pengalaman yang minim

Nilai original sample untuk variabel moderator gender adalah 0,74 bernilai negatif. Lalu nilai original sample untuk moderator age adalah 0,15 bernilai negatif serta nilai original sampel untuk experience adalah positif 0,24. Dari nilai original sample ini dapat terlihat bahwa variabel moderator tidak bernilai positif memoderatori facilitating condition terhadap behavioral intention. Untuk P value-nya sendiri berturut-turut adalah senilai 0.440 , 0,886 dan 0.835. Nilai tersebut tidak memenuhi syarat yang telah ditentukan. Sementara untuk $\mathrm{T}$ value dari variabel moderator gender adalah 0,772, lalu untuk age adalah 0,143 dan experience senilai 0,209. Seluruh nilai dari original sample, $\mathrm{P}$ value hingga $\mathrm{T}$ value tidak memenuhi syarat yang ada sehingga hipotesis 0 ditolak dan hipotesis a diterima $\left(\mathbf{H}_{\mathbf{0}}\right.$ : $\operatorname{ditolak}, \mathbf{H}_{\mathrm{a}}$ : diterima).

6. $\mathrm{H}_{0}$ : Facilitating condition akan berpengaruh positif dan signifikan terhadap use behavior e-commerce shopee di kota Palembang

$\mathrm{H}_{\mathrm{a}}$ : Facilitating condition tidak akan berpengaruh positif dan signifikan terhadap use behavior e-commerce shopee di kota Palembang

Dengan melihat hasil perhitungan pada tabel Path Coefficient dapat dikatakan bahwa hipotesis $\mathrm{H}_{0}$ dapat diterima. Karena memiliki $\mathrm{T}$ value lebih besar dari 1,96 yakni sebesar 2,762 dan memiliki P value lebih kecil dari 0,05 yakni 0,006. Sehingga pada penelitian ini variabel moderator yaitu Age, gender dan experience akan memoderatori pengaruh dari facilitating condition terhadap use behavior. $\left(\mathbf{H}_{\mathbf{0}}\right.$ : diterima $\mathbf{H}_{\mathbf{a}}$ : ditolak). Didukung dengan hasil uji $\mathrm{F}$ square yang menunjukkan bahwa variabel facilitating condition memiliki effect size sebesar 0,140 yang mana memiliki jumlah yang lebih besar dari variabel-variabel sebelum dan hampir tergolong pada modest effect size. Artinya variabel facilitating condition memiliki efektivitas terhadap use behavior.

7. $\mathrm{H}_{0}$ : Hedonic motivation akan berpengaruh positif dan signifikan terhadap perilaku pelanggan (behavioral intention) e-commerce shopee di kota Palembang 
$\mathrm{H}_{\mathrm{a}}$ : Hedonic motivation tidak akan berpengaruh positif dan signifikan terhadap perilaku pelanggan (behavioral intention) e-commerce shopee di kota Palembang

Hasil pengujian hipotesis menunjukkan bahwa nilai original sample bernilai positif 0,109 , T value 1,051 dan $\mathrm{P}$ value 0,294 . Hal ini menunjukkan bahwa Hedonic motivation berpengaruh positif namun tidak berpengaruh signifikan terhadap behavioral intention sehingga hipotesis 0 ditolak dan hipotesis a diterima $\left(\mathbf{H}_{0}\right.$ : ditolak, $\mathbf{H}_{\mathbf{a}}$ : diterima). Uji hipotesis ini diperkuat dengan hasil uji $\mathrm{F}$ square yang menunjukkan bahwa Hedonic motivation memiliki efektivitas yang lemah terhadap behavioral intention yakni dengan nilai 0,024.

8. $\mathrm{H}_{0}$ : Age, gender dan experience akan memoderatori pengaruh bedonic motivation terhadap behavioral intention pelanggan e-commerce shopee di kota Palembang yang mana akan memiliki efek yang lebih besar kepada lakilaki muda dengan pengalaman yang minim

$\mathrm{H}_{\mathrm{a}}$ : Age, gender dan experience tidak akan memoderatori pengaruh bedonic motivation terhadap behavioral intention pelanggan e-commerce shopee di kota Palembang yang mana akan memiliki efek yang lebih besar kepada lakilaki muda dengan pengalaman yang minim

Nilai original sample berturut-turut untuk variabel moderator hedonic motivation adalah $0.052,0.133$ dan negatif 0,187 . Untuk nilai $T$ value variabel moderator Age, gender dan experience adalah 0.424, 1.249 dan 1.196 serta nilai $\mathrm{P}$ value berturut-turut adalah $0.671,0.212$ dan 0,232 . Semua angka yang dihasilkan oleh tabel path coefficient terhadap variabel moderator tidak ada yang memenuhi syarat untuk hipotesis diterima. Oleh karena itu Age, gender dan experience tidak memoderatori pengaruh hedonic motivation terhadap behavioral intention sehingga hipotesis 0 ditolak dan hipotesis a diterima $\left(\mathbf{H}_{0}\right.$ : ditolak, $\mathbf{H}_{\mathbf{a}}$ : diterima).

$\mathrm{H}_{0}$ : Price value akan berpengaruh positif dan signifikan terhadap perilaku pelanggan (behavioral intention) e-commerce shopee di kota Palembang $\mathrm{H}_{a}$ : Price value tidak akan berpengaruh positif dan signifikan terhadap perilaku pelanggan (behavioral intention) e-commerce shopee di kota Palembang

Nilai yang dimiliki variabel price value untuk original sample pada tabel hasil anlisis adalah sebesar 0,048 dan bernilai positif. Lalu memiliki $\mathrm{P}$ value senilai 0,634 dan T value sebesar 0,476. Angka-angka tersebut sangat jauh dari ketetapan yang ada yaitu $\mathrm{P}$ value harus $<0,05$ dan $\mathrm{T}$ value $>1,96$. Jadi, dapat di simpulkan intention hipotesis 0 ditolak dan hipotesis a diterima $\left(\mathbf{H}_{0}\right.$ : ditolak, $\mathbf{H}_{\mathbf{a}}$ : diterima) dikarenakan price value tidak berpengaruh secara signifikan terhadap behavioral intention. 
Vol. 3, No. 2, June 2021

p-ISSN: 2656-5935 http://journal-isi.org/index.php/isi

e-ISSN: 2656-4882

9. $\mathrm{H}_{0}$ : Age dan gender akan memoderatori pengaruh price value terhadap behavioral intention pelanggan e-commerce shopee di kota Palembang yang mana akan memiliki efek yang lebih besar kepada perempuan yang berusia lebih tua

$\mathrm{H}_{\mathrm{a}}$ : Age dan gender tidak akan memoderatori pengaruh price value terhadap behavioral intention pelanggan e-commerce shopee di kota Palembang yang mana akan memiliki efek yang lebih besar kepada perempuan yang berusia lebih tua

Hasil uji statistik pada penelitian ini menujukan bahwa hipotesisi ini tidak dapat diterima dikarenaka $\mathrm{T}$ value serta $\mathrm{P}$ value tidak memenuhi standar yang dibutuh kan. T value terhadap variabel moderator price value berturutturut adalah 0,301 dan 1,241. Sedangkan untuk $\mathrm{P}$ value-nya bernilai 0,763 untuk gender dan 0,215 untuk age. Sehingga hipotesis 0 ditolak dan hipotesis a diterima $\left(\mathbf{H}_{\mathbf{0}}\right.$ : ditolak, $\mathbf{H}_{\mathbf{a}}$ : diterima). Age dan gender tidak memoderatori pengaruh price value terhadap behavioral intention.

10. $\mathrm{H}_{0}$ : Habit akan berpengaruh positif dan signifikan terhadap perilaku pelanggan (behavioral intention) e-commerce shopee di kota Palembang

$\mathrm{H}_{\mathrm{a}}$ : Habit tidak akan berpengaruh positif dan signifikan terhadap perilaku pelanggan (behavioral intention) e-commerce shopee di kota Palembang

Hasil dari perhitungan data yang ada menyatakan bahwa untuk variabel habit memiliki nilai original sample $(\mathrm{O})$ sebesar 0,542 yang bernilai positif. Berarti variabel bernilai positif terhadap behavioral intention. Namun, T value-nya menujukkan nilai 4,755 dan P value yang bernilai 0,000 yang mana nilai tersebut memenuhi standar yang sudah ditetapkan yakni $\mathrm{P}$ value harus $<0,05$ dan $\mathrm{T}$ value $>1,96$. Maka, dapat dinyatakan bahwa Habit berpengaruh positif dan signifikan terhadap behavioral intention $\mathbf{~}_{\mathbf{0}}$ : diterima, $\mathbf{H}_{\mathbf{a}}$ : ditolak). Sejalan denga hasil uji $\mathrm{F}$ square dimana variabel babit menduduki peringkat pertama dengan effect size tertinggi dibanding dengan variabel-variabel lain. Dengan nilai F square sebesar 0,512 yang menjadi bukti bahwa habit memiliki efektivitas terhadap behavioral intention . Dengan angka tersebut, habit tergolong pada effect size moderate atau pada tingkat menengah.

11. $\mathrm{H}_{0}:$ Age, gender dan experience akan memoderatori pengaruh habit terhadap behavioral intention pelanggan e-commerce shopee di kota Palembang yang mana akan memiliki efek yang lebih besar kepada laki-laki berusia lebih tua dengan pengalaman yang cukup 
$\mathrm{H}_{\mathrm{a}}$ : Age, gender dan experience tidak akan memoderatori pengaruh habit terhadap behavioral intention pelanggan e-commerce shopee di kota Palembang yang mana akan memiliki efek yang lebih besar kepada laki-laki berusia lebih tua dengan pengalaman yang cukup

Dari hasil penilaian statistik dapat ditarik kesimpulan bahwa hipotesis hipotesis 0 ditolak dan hipotesis a diterima. Dikarenaka T value dan $\mathrm{P}$ value tidak memenuhi syarat yang telah ditetapkan. Secara berturut-turut $\mathrm{T}$ value pada hipotesis ini adalah 1.182, 0.969 dan 1,013. Serta memiliki P value yaitu $0.238,0.333$ dan $0,312\left(\mathbf{H}_{0}\right.$ : ditolak, $\mathbf{H}_{\mathbf{a}}$ : diterima).

12. $\mathrm{H}_{0}$ : Habit akan berpengaruh positif dan signifikan terhadap use behavior ecommerce shopee di kota Palembang

$\mathrm{H}_{\mathrm{a}}$ : Habit tidak akan berpengaruh positif dan signifikan terhadap use behavior e-commerce shopee di kota Palembang

Dari yang tertulis pada tabel Path Coefficient diatas dapat diliihat bahwa variabel habit terhadap use behavior memiliki nilai original sample sebesar negatif 0,065 . Lalu memiliki nilai $\mathrm{T}$ value 0,367 dan $\mathrm{P}$ value 0,714 dimana nilai $\mathrm{P}$ value harus $<0,05$ dan $\mathrm{T}$ value $>1,96$. Yang berarti bahwa habit tidak berpengaruh positif dan signifikan terhadap use behavior sehingga hipotesis 0 ditolak dan hipotesis a diterima $\left(\mathbf{H}_{0}\right.$ : ditolak, $\mathbf{H}_{\mathbf{a}}$ : diterima). Hal ini pula dapat dibuktikan dengan hasil uji $\mathrm{F}$ square yang menyatakan bahwa habit terhadap use behavior hanya memiliki efektivitas sebesar 0,002 dimana tergolong pada effect size lemah bahkan hampir tidak berpengaruh. $\mathrm{H}_{0}$ : Age, gender dan experience akan memoderatori pengaruh babit terhadap use behavior pelanggan e-commerce shopee di kota Palembang yang mana akan memiliki efek yang lebih besar kepada laki-laki berusia lebih tua dengan pengalaman yang cukup.

$\mathrm{H}_{\mathrm{a}}$ : Age, gender dan experience tidak akan memoderatori pengaruh habit terhadap use behavior pelanggan e-commerce shopee di kota Palembang yang mana akan memiliki efek yang lebih besar kepada laki-laki berusia lebih tua dengan pengalaman yang cukup

Hasil perhitungan statistik menunjukkan bahwa experience tidak memoderatori habit terhadap use behavior karena memiliki nilai $\mathrm{T}$ value dan $\mathrm{P}$ value yang tidak memenuhi standar. $\mathrm{T}$ value yang dimiliki variabel moderator ini adalah 0,740, 0,440 dan 0,078. Sementara memiliki P value dengan nilai $0,459,0,660$ dan 0,938 . Sehingga hipotesis 0 ditolak dan hipotesis a diterima $\left(\mathbf{H}_{\mathbf{0}}\right.$ : ditolak, $\mathbf{H}_{\mathbf{a}}$ : diterima $)$. 
13. $\mathrm{H}_{0}$ : Behavioral intention akan berpengaruh positif dan signifikan terhadap use behavior e-commerce shopee di kota Palembang

$\mathrm{H}_{\mathrm{a}}$ : Behavioral intention tidak akan berpengaruh positif dan signifikan terhadap use behavior e-commerce shopee di kota Palembang

Menurut hasil yang didapat dari perhitungan statistik menunjukkan bahwa behavioral intention memiliki nilai original sample sebesar 0,330 yang bernilai positif. Hal ini berarti behavioral intention memiliki pengaruh positif terhadap use bahavior. Namun, hal ini tidak didukung oleh T value yang bernilai 1,173 dan P value 0.077 yang mana tidak memenuhi ketetapan yang sudah ada. Sehingga dapat diartikan bahwa behavioral intention berpengaruh positif namun tidak berpengaruh signifikan terhadap use behavior sehingga hipotesis 0 ditolak dan hipotesis a diterima $\left(\mathbf{H}_{0}\right.$ : ditolak, $\mathbf{H}_{\mathbf{a}}$ : diterima). Hal ini pula didukung oleh nilai $\mathrm{F}$ square dimana menunjukkan efektivitas behavioral intention terhadap use behavior hanya sebesar 0,053 yang tergolong pada effect size lemah. Oleh karena itu, dapat disimpulkan berdasarkan hasil uji hipotesis pada penelitian ini bahwa pengguna yang memiliki behavioral intention terhadap shopee belum tentu memiliki use behavior yang sama untuk menggunakan aplikasi shopee.

14. $\mathrm{H}_{0}$ : Experience akan memoderasi pengaruh behavioral intention terhadap use behavior yang pengaruhnya akan lebih kuat bagi pengguna dengan pengalaman yang kurang

$\mathrm{H}_{\mathrm{a}}$ : Experience tidak akan memoderasi pengaruh behavioral intention terhadap use behavior yang pengaruhnya akan lebih kuat bagi pengguna dengan pengalaman yang kurang

Dari data yang didapat dari tabel Path Coefficient diatas, hipotesis 0 ditolak dan hipotesis a diterima $\left(\mathbf{H}_{\mathbf{0}}\right.$ : ditolak, $\mathbf{H}_{\mathbf{a}}$ : diterima) karena $\mathrm{T}$ value dan $\mathrm{P}$ value tidak memenuhi syarat yakni bernilai 0,831 dan 0,406 yang seharusnya $\mathrm{P}$ value $<0,05$ dan T value $>1,96$. Sehingga disimpulkan bahwa Experience tidak memoderasi pengaruh behavioral intention terhadap use behavior.

\section{KESIMPULAN}

Berdasarkan hasil analisis dengan menggunakan pendekatan model UTAUT 2 dan metode SEM-PLS maka kesimpulan yang dapat ditarik dari penelitian ini adalah :

1. Dari tujuh variabel yang ada, terdapat dua variabel yang berpengaruh secara langsung terhadap niat perilaku pelanggan atau behavioral intention (Y1) yaitu social influence (X3) dan habit (X7). 
Vol. 3, No. 2, June 2021

p-ISSN: 2656-5935 http://journal-isi.org/index.php/isi e-ISSN: 2656-4882

2. Niat penggunaan atau use behavior (Y2) dipengaruhi secara langsung oleh variabel facilitating condition (X4).

3. Variabel lain seperti performance expectancy, effort expectancy, hedonic motivations dan price value tidak memiliki pengaruh terhadap behavioral intention dan use behavior pelanggan E-Commerce Shopee Indonesia di kota Palembang.

4. Semakin tinggi pengaruh sosial dan lingkungan dari pengguna aplikasi Shopee, maka akan semakin tinggi pula niat perilaku dari pelanggan tersebut. Pengaruh tersebut dapat berupa ajakan dari orang lain untuk berbelanja ataupun hanya sekedar melihat-lihat produk pada aplikasi shopee.

5. Aktivitas yang dilakukan secara konsisten dan terus-menerus dalam penggunaan aplikasi shopee dapat mempengaruhi niat perilaku untuk seterusnya karena aktivitas tersebut menjadi kebiasaan (habit) yang dilakukan secara spontan.

6. Niat penggunaan (use behavior) dapat dipengaruhi oleh kondisi fasilitas yang artinya ketika pelanggan memiliki fasilitas yang memadai seperti smartphone atau laptop, jaringan internet hinggan fasilitas seperti bantuan dalam penggunaan aplikasi. Hal akan meningkatkan niat penggunaan pelanggan di kota Palembang terhadap aplikasi Shopee.

7. Dari keseluruhan faktor yang digunakan untuk mengukur behavioral intention, berdasarkan tabel adjusted $\mathrm{R}$ kontribusi yang terhitung pada penelitian ini sebesar $75 \%$. Sementara $25 \%$ lagi ditentukan oleh faktor lain diluar penelitian. Sedangkan untuk use behavior, pemodelan pada penelitian ini hanya mampu mengindikasi tingkat penggunaan aplikasi. shopee oleh pelanggan di kota Palembang sebesar 36\% dan sisanya sebesar 64\% dipengaruhi oleh faktor lain diluar penelitian

\section{DAFTAR PUSTAKA}

[1] L. N. Ardhiani, "Analisis Faktor-faktor Penerimaan Penggunaan Quipperschool. com dengan Menggunakan Pendekatan Technology Acceptance Model (TAM) dan Theory of Planned Behavior (TPB) di SMA Negeri 7 Yogyakarta," vol. 4. p. 2017, 2015.

[2] S. A. Brown and V. Venkatesh, "Model of adoption of technology in households: A baseline model test and extension incorporating household life cycle,” MIS quarterly. JSTOR, pp. 399-426, 2005. 
[3] V. D. Devita, "Report: Peta Persaingan E-Commerce Indonesia Q4 2020." 2020, [Online]. Available: https://iprice.co.id/trend/insights/petapersaingan-e-commerce-2020/.

[4] R. B. Dwifany, "THE DETERMINANTS OF INDIVIDUAL INTEREST TO BUY PRODUCT AT SHOPEE," Jurnal Ilmiah Mahasiswa FEB, vol. 8, no. 2. 2020.

[5] J. Griffin, "Customer loyalty." Esensi, 1995.

[6] A. Hasan, "Marketing dari mulut ke mulut," Yogyakarta: Media Pressindo. 2010.

[7] G. C. Moore and I. Benbasat, "Integrating diffusion of innovations and theory of reasoned action models to predict utilization of information technology by end-users," Diffusion and adoption of information technology. Springer, pp. 132-146, 1996.

[8] H. O. Putri and others, "Penerapan Metode Unified Theory of Acceptence and Use of Technology (UTAUT) dalam Memprediksi Behavioral Intentions pada Penggunaan E-Commerce Shopee di Kalangan Mahasiswa (Studi Kasus di Fakultas Tarbiyah dan Keguruan UIN Ar-Raniry)." 2019.

[9] S. Sutanto, I. Ghozali, and R. S. Handayani, "Faktor-Faktor Yang Memengaruhi Penerimaan Dan Penggunaan Sistem Informasi Pengelolaan Keuangan Daerah (Sipkd) Dalam Perspektif the Unified Theory of Acceptance and Use of Technology 2 (Utaut 2) Di Kabupaten Semarang," Jurnal Akuntansi dan Auditing, vol. 15, no. 1. Department of Accounting, Faculty of Economics \\& Business, Diponegoro ..., pp. 37-68, 2018.

[10] Tia Dwitiani Komalasari, "BELANJA ONLINE MENINGKAT 400 PERSEN, BPKN : MASIH BANYAK DIKELUHKAN

KONSUMEN.” Jun. 2020, [Online]. Available: https://www.pikiranrakyat.com/ekonomi/pr-01399518/belanja-online-meningkat-400-persenbpkn-masih-banyak-dikeluhkan-konsumen.

[11] V. Venkatesh and F. D. Davis, "A theoretical extension of the technology acceptance model: Four longitudinal field studies," Management science, vol. 46, no. 2. INFORMS, pp. 186-204, 2000.

[12] V. Venkatesh, M. G. Morris, G. B. Davis, and F. D. Davis, "User acceptance of information technology: Toward a unified view," MIS quarterly. JSTOR, pp. 425-478, 2003.

[13] V. Venkatesh, J. Y. L. Thong, and X. Xu, "Consumer acceptance and use of information technology: extending the unified theory of acceptance and use of technology," MIS quarterly. JSTOR, pp. 157-178, 2012. 